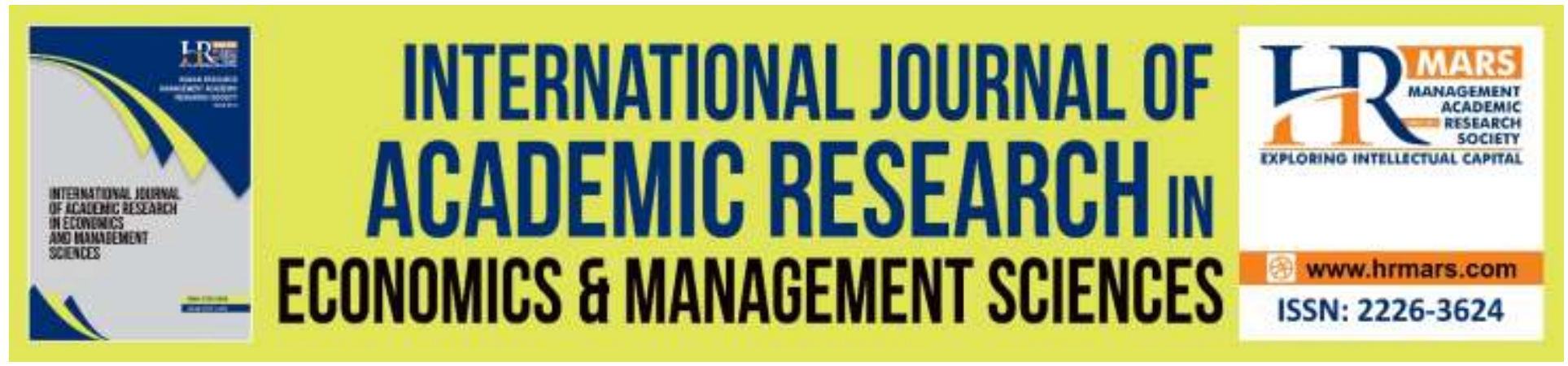

\title{
Effect of Fiscal Deficit on Selected Macroeconomic Variables in Nigeria: A Time Series Analysis, 1986-2018
}

Obinabo, Chinyere Rose, AGU, Bertram Onyebuchi

To Link this Article: http://dx.doi.org/10.6007/IJAREMS/v7-i3/6276

DOI: $10.6007 /$ IJAREMS/v7-i3/6276

Received: 13 July 2018, Revised: 09 August 2018, Accepted: 01 Sep 2018

Published Online: 18 Sep 2018

In-Text Citation: (Obinabo \& AGU, 2018)

To Cite this Article: Obinabo, C. R., \& AGU, B. O. (2018). Effect of Fiscal Deficit on Selected Macroeconomic Variables in Nigeria: A Time Series Analysis, 1986-2018. International Journal of Academic Research in Economics and Management Sciences, 7(3), 78-91.

Copyright: ( 2018 The Author(s)

Published by Human Resource Management Academic Research Society (www.hrmars.com)

This article is published under the Creative Commons Attribution (CC BY 4.0) license. Anyone may reproduce, distribute, translate and create derivative works of this article (for both commercial and non-commercial purposes), subject to full attribution to the original publication and authors. The full terms of this license may be seen

at: http://creativecommons.org/licences/by/4.0/legalcode

Vol. 7, No. 3 (2018), Pg. 78 - 91

http://hrmars.com/index.php/pages/detail/IJAREMS

JOURNAL HOMEPAGE

Full Terms \& Conditions of access and use can be found at http://hrmars.com/index.php/pages/detail/publication-ethics 


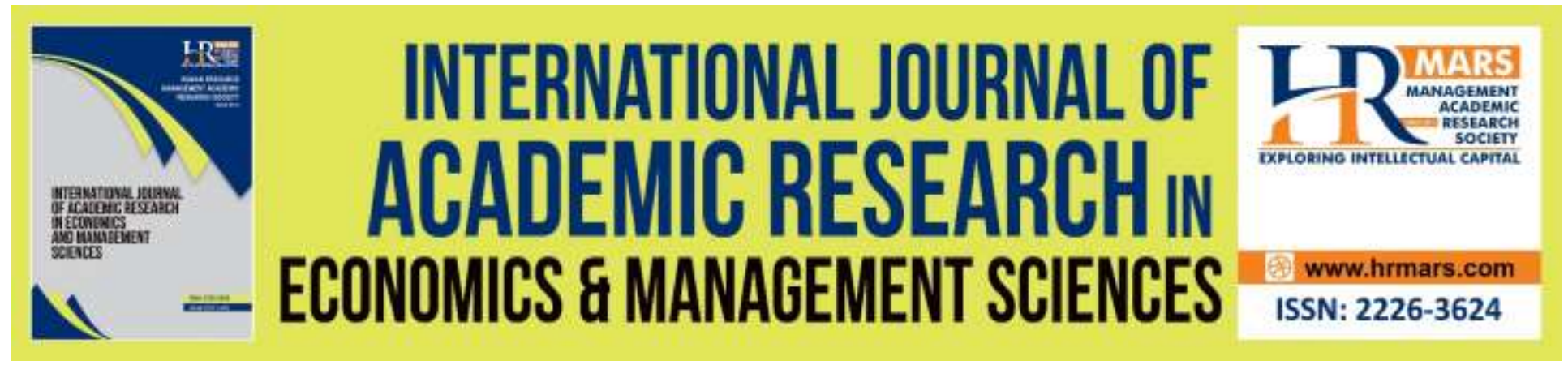

\title{
Effect of Fiscal Deficit on Selected Macroeconomic Variables in Nigeria: A Time Series Analysis, 1986- 2018
}

\author{
Obinabo, Chinyere Rose Ph.D, CICMA. \\ Department of Accountancy, Faculty of Management Sciences, \\ Ebonyi State Univesity, Abakaliki \\ AGU, Bertram Onyebuchi, PhD \\ Department of banking and finance \\ Enugu state university of science and technology, ESUT Enugu
}

\begin{abstract}
This study investigated the effect of fiscal deficit on selected macroeconomic variables in Nigeria. Specifically the study examined the effects of fiscal deficit on Nigeria's gross domestic product, determine the impact of fiscal deficit on the level of Money Supply in Nigeria, and ascertain the relationship between fiscal deficit and Inflation Rate in Nigeria. To achieve these objectives, the study employed various econometric techniques such as unit root test, Johansen co-integration, ordinary least square and granger causality test in which variations in the independent variables were regressed on the dependent variable using time series data from 1986-2018. Secondary data casing the time frame were collected from Central Bank of Nigeria statistical bulletin. The results of the analysis indicates that (i) Fiscal Deficit (FD) has positive and no significant effect on Gross Domestic Product (GDP) (ii)Fiscal Deficit (FD) has negative and no significant impact on Money Supply (MS) (iii) Fiscal Deficit (FD) has negative and no significant relationship with Inflation Rate (INFR).The study recommended among others that government should set its priority rights, be more committed to budget implementation and to pay more attention to capital expenditure geared towards growth. Systemic corruption which is the main reason why fiscal deficit has not positively impacted on macroeconomic indicators should be dissuaded in Nigeria. The study further recommended that key government institutions should mount programs that are directed towards restoring the value system, norms and mind-set of Nigerians which corruption has destabilized and made weak to be strong again, otherwise, Nigeria will systematically drift into extinction.
\end{abstract}

Keywords: Fiscal Deficit, Macroeconomic Variables, Secondary Data, Interest Rate, Inflation Rate. 
INTERNATIONAL JOURNAL OF ACADEMIC RESEARCH ECONOMICS AND MANAGEMENT SCIENCES Vol. 7, No. 3, 2018, E-ISSN: 2226-3624 @ 2018 HRMARS

\section{Introduction}

An economic situation where expected current expenditure exceeds expected current income is known as Fiscal Deficit. The effectiveness of Fiscal deficits depends on the realization of its goals. This means that it is a means to an end and not an end in itself (Ubi and Inyang, 2018). The end in this situation is ensuring the stabilization of prices, economic development and enhances improvement in the standard of living. Given that it is not an end in itself; its usefulness depends on its ability to achieve the goals which the policy architects set out (Anyanwu and Oaikhenan 1995)

In Nigeria, government has always relied more on fiscal policy as a key to solving her economic issues. These policies were anchored on Keynesian economic assumptions of increasing or reducing government spending and reducing or increasing taxes and subsidies. In the 1980s, federal government expenditure had grown significantly resulting in fiscal predicaments, inflation and other economic crisis. The low level of private sector driven development, however, led to public sector control of the economy, facilitated by growth in Nigeria's oil sector. Consequently, through the austerity measures implemented in 1982 and Structural Adjustment Programme (SAP) introduced in 1986, the country drastically reduced public expenditure by government as a component of its stabilization and adjustment programmes (Ubi and Inyang, 2018).These cutbacks in public expenditure resulted in unmatched economic and social costs as human resource development was abandoned and with adverse long-term development costs (Oyinlola and Adam, 2003 in Ubi and Inyang, 2018).

For over thirty two years (32), between 1986 and 2018, the nature of public expenditure operations of the Nigerian government had resulted in deficits and surpluses in two years (1995 and 1996). In spite of these and the eventual implementation of SAP, those problems and constraints in the Nigerian economy are still with us. Worse among them are the continued heavy reliance on the oil sector as the main source of foreign income inflow and government revenue, the twin evils of inflation and unemployment, the burden of both external and internal debts, the disturbing issue of low productivity in agriculture, manufacturing and the economy in general. This has been attributed to some factors which include social and religious crisis, mismanagement of available resources, corruption, fall in the price of oil in the world market and unprecedented increase in economic activities. This has made the incidence of fiscal deficits inevitable (Egwaikhide, 1994 and CBN, 2006). It is worthy of note that since the beginning of civilian rule in 1999 and post economic crisis of 2008, output growth in Nigeria has improved significantly. The last fourteen years spanning from 2000 to 2014 for example witnessed average growth rate of about 6 percent (CBN, 2015). However, economic growth has not yielded any appreciable decline in unemployment and poverty reduction despite the huge fiscal deficits of the federal government

. From the fore going, it becomes necessary to appraise the effect of fiscal deficits on selected macroeconomic variables in Nigeria since 1986 to 2018 with a view to finding out its contributions in the development efforts of the nation.

\section{Statement of the Problem}

In Nigeria, fiscal expenditure is made possible by unprecedented earnings from oil sales which most often than not is alternated by periods of oil glut that leads to significant declines in government revenues. As government is always unwilling to reduce the bloated expenditures 
that had resulted during the oil boom periods, they are forced to seek alternative means of financing their expenditures. Thus, governments resort to fiscal deficits. Fiscal deficits have become a recurring decimal of public sector financing in Nigeria. The peculiarity of fiscal deficits in Nigeria is that it is skewed heavily in favour of recurrent expenditure (60 per cent recurrent expenditure and 40 percent capital expenditure) which does not necessarily drive economic development. Since one of the critical instruments of fiscal policy is fiscal deficits, hence, stabilization of prices, growth of per capita income, and employment requires that fiscal deficit itself must grow or expand at a low constant rate. The Nigeria experience is completely at variance with the idea expressed above. Fiscal deficits have been growing at a rate that is alarmingly not constant. Research shows that, the growth rate of fiscal deficits raised from 97.55 per cent in 1981 to 171.54 per cent in 1986 and rose to 3104.94 per cent in 1996 respectively. Fiscal deficit growth rate was negative (- 115.60 per cent) in 1997, but increased sharply to 2567.78 per cent in 1998 and declined to 2.07 per cent in 2016. Between 1998 and 2016, the deficit growth rate has been rising and falling. This clearly shows that fiscal deficit has not been growing at a constant rate.

This study therefore seeks to build on existing literature in this subject area in order to contribute to the existing body of knowledge. In view of the above, this study sets out to appraise the effect of Fiscal Deficit on selected microeconomic variables such as Money Supply, Inflation Rate, and Gross Domestic Products (GDP) in Nigeria.

This study is structured into five sections. The second section is the review of related literature, in which conceptual, theoretical, and empirical issues that are related to this study were reviewed. Section three is the methodology of the study. Section four is data presentation and analysis. Section five concludes the study with a summary of findings, conclusion and recommendations.

\section{Review of Related Literature Conceptual Framework}

Fiscal Deficit refers to the financial situation wherein the government's total budget exceeds the total receipts excluding borrowings made during the fiscal year. Thus, it can be expressed as: Fiscal Deficit $=$ Total Expenditure - Total Receipts Excluding Borrowings

Through Fiscal deficit, the government can determine the amount that needs to be borrowed in case it lacks adequate resources.

The fiscal deficit can occur even if the revenue deficit is not there if the following conditions prevail:

Revenue budget is balanced, but the capital budget is in deficit.

Revenue budget is in the surplus, and the capital budget is in deficit, and the deficit is more than the surplus.

Gross Domestic Product: Gross domestic product is the total value of all final goods and services produced within a given country in a given year. It is also the market value of all officially recognized final goods and services product within a country in a given period of time. Deficit will affect gross domestic product if there are more deficits then the gross domestic product and that will rise as the government might have involved in planed expenditure and if it is non-plan 
INTERNATIONAL JOURNAL OF ACADEMIC RESEARCH ECONOMICS AND MANAGEMENT SCIENCES Vol. 7, No. 3, 2018, E-ISSN: 2226-3624 ㄷ 2018 HRMARS

expenditure it will affect the gross domestic product as this expenditure will not bring benefits to the country (Adesuyi \& Falowo, 2013)

Money Supply: The term money supply refers to the amount in the hands of the non-bank public at a point in time and the some balances in commercial banks. The Central Bank of Nigeria (CBN) as well as public and private analysts shows interest in the growth of money supply because of the impact it is believed to have on real economic activities and the general price level. The growth of money supply will lead to inflation if increase in money supply is not met by equal increase in demand (Umeora, 2010). According to the Ricardian view the fiscal deficits have no impact on money supply in the long run but according to the Neoclassical and Keynesians view there are significant and positive relationship between fiscal deficits and money supply in the short run (Saad \& Kalakech, 2009).

\section{Inflation}

Inflation is the creation of money that visibly raises prices of goods and lowers the purchasing power of Naira. The relationship between government fiscal deficits and inflation has attracted enormous debate over the years. First, direct impact through aggregate demand, an increase in aggregate demand leads to inflation. Secondly, direct impact through the money supply, large fiscal deficits lead to increases in the money supply which in turn increase the price level. Thirdly, an impact through interest rates, increases in fiscal deficits lead to higher interest rates which crowd out private investment, and hence reduce aggregate supply, which leads to price increases and finally, higher inflation expectations lead to higher real interest rate and higher debt-service cost which leads to increase in fiscal deficits (Barro, 1979). The inflationary effect of fiscal deficits through bond issues, it could lead to inflation if tight monetary policy is used and otherwise. If seignior age revenue is used to finance deficit, the implication is that fiscal deficit will lead to inflation.

\section{Theoretical Framework}

The theoretical frame work of this study is anchored on Ricardian Equivalence Theory

This theory holds that fiscal deficits, irrespective of how they are financed would have an insignificant or no effect on private consumption and interest rates. But this would depend on some suppositions. The suppositions are that: a) individuals internalize both the government's budget constraint and the utility of their offspring; b) the capital market is well-organized, such that the interest rate is the same for borrowers and lenders; and c) distorting taxes are nonexistent.

Barro (1989) opined that this theory (Ricardian equivalence) implies that taxpayers do not see government bonds as net wealth. Thus, its acquisition by individuals does not change their consumption behaviour. In view of this, it was concluded that the impact of government expenditure in a closed economy will be invariant to tax versus bond financing. Fiscal deficit therefore simply represents a transfer of spending resources from the private to the public sector and variation in fiscal deficit is neutral to economic activity (Chakraborty and Chakraborty, 2006). Fiscal deficit, according to this theory, also has no impact on private investment. Accordingly, a decline in taxes, accompanied by a rise in deficit expenditure, does not trigger consumption growth, and hence does not have any expansionary effect as family units tend to increase savings 
in anticipation of higher taxes in the future, which are necessary to redeem the debt (Okpanachi and Abimiku, 2007). Similarly, the Ricardian equivalence theory holds that tax-financed government deficits or debts do not have any effect on the trade balance and the real exchange rate and hence the absence of a relationship between deficit expenditure and current account deficit (Barro, 1989, Neaime, 2008 and Okpanachi and Abimiku, 2007).

\section{Empirical Review}

Ubi and Inyang (2018) descriptively appraised fiscal deficit and its implication on Nigeria's economic development from 1980 to 2016. The study appraised fiscal deficit in relation to some identified indicators of development such as per capita income, economic growth (GDP), unemployment, inflation and Balance of payment (BOP). It was discovered that Nigeria's fiscal deficit has contributed positively to the growth of per capita income, economic growth and stabilization of Balance of payment only. Fiscal deficit did not reduce unemployment and inflation rates within the period of study.

Nwaeze (2017) examined empirically the relationship between fiscal deficit and macroeconomic stability in Nigeria from 1970 to 2016. The data for empirical analysis was sourced from secondary sources such as the CBN statistical bulletin. The study employed descriptive statistics, unit root test, co-integration and VAR estimation methods to analyze the data. The results of the variance decomposition reveal that interest rate, overall fiscal deficits and the size of fiscal deficits financed by domestic borrowing are the main shocks causing the variation in exchange rate in Nigeria. The study concludes that fiscal deficits have significant and negative impact on microeconomic stability vis-aviz inflation and exchange rates

Sanya and Abiola (2015) examined the impact of fiscal deficit on the growth of Nigerian economy using co-integration and error correction model. The time series property of the data employed, are first investigated. This followed by testing for co-integrated variables. From the unit root test, the result clearly indicated that the variables are integrated of the same order at first difference. Also from the multivariate co-integration test, within the Auto-Regressive Distribution Lag (ARDL) the results indicate that there are, at most, two co-integrating vectors.

Aslam (2016) tested the dynamic relationship between the fiscal deficit and the economic growth of Sri-Lanka using annual time series data from 1959-2013. To test this objective, the fiscal deficit of Sri-Lanka was used as independent variable and the gross domestic product in constant price was utilized as dependent variable. The exports earnings, exchange rate, inflation rate were used as supportive independent variables of the study. The Johansen co-integration technique and Vector Error Correction Model were employed to test the long and short-run dynamic relationship between the fiscal deficit and the economic growth of Sri Lanka.

Umeora \& Ikeora (2016) investigated the effects of government fiscal deficits on money supply in Nigeria. Because effect of money supply on inflation is almost always inseparable, effect of inflation has also been brought in. Data for the study are secondary data set for 1970-2014 were obtained from CBN Statistical Bulletin. The method of analysis was Error Correction Model (ECM) and Pairwise Granger Causality. The regression results showed that government fiscal deficits 
have significant and negative effect on money supply and the inflation does not contribute significantly to money supply and fiscal deficits. Pairwise Granger Causality indicates that money supply granger cause fiscal deficits.

Ozurumba (2012) examined the causal relationship between inflation and fiscal deficits in Nigeria, covering the period 1970-2009. This was carried out by way of developing an estimation model of inflation and fiscal deficit, with a view to testing causes and effects as well as the relationship between them. The estimation technique used was the autoregressive distributed lag (ARDL) model and the Granger-causality test. The rest of the Granger-causality test shows that the null hypothesis which says that fiscal deficit does not cause inflation should be rejected since the result is significant with probability less than 0.05 . This implies that fiscal deficit/GDP causes inflation. However, no feedback mechanism was observed. The results from the ARDL test confirm a significant negative relationship between growth in fiscal deficit (\% of GDP) and inflation.

\section{Methodology \\ Research Design}

This research used ex-post facto research design. The ex-post facto research design also known as causal comparative research involves the ascertaining of past factors on the present happening of an event. It means finding out if an event that occurred in the past has any influence in bringing about the present event. A combination of descriptive statistics, covariance test, correlation and regression were employed in carrying out the necessary preliminary and diagnostic test. Augmented Dickey Fuller (ADF) test was used for unit root test. The design adopted is used to evaluate the relationship between Fiscal Deficit and selected macroeconomic variables in Nigeria. The researcher also made use of correlation coefficient analysis to measure the magnitude of relationship that exists between fiscal deficit and macroeconomic variable in Nigeria.

\section{Nature and Sources of Data}

The main type of data used in this study is secondary; sourced from Central Bank of Nigeria statistical Bulletin and Nigerian Economic Indicators various issues for the period of $1986-2018$. The research variables are structured into dependent and independent variables. The dependent variable of the research is fiscal deficit (FD) while the independent variables are Money supply, Inflation rate and Gross Domestic Product.

\section{Model Specification}

Model is a simplified view of reality designed to enable a researcher describe the essence and inter relationship within the system or phenomenon it depicts. The objectives of the study were analyzed using the Ordinary Least Square (OLS) Regression Model.

The model used in this study was adopted from the work of Ajekwe, Korna and Idyu (2013) with little modifications to suit this study.

The model specification used in this study is stated as follows;

$$
\text { FD = } f \text { (MS, INFR, GDP) --------------3.3.1 }
$$

We can also specify the above equation in an econometric form; 
$F D=\beta 0+\beta_{1} M S+\beta_{2}$ INFR $+\boldsymbol{\beta}_{3}$ GDP $+\boldsymbol{\mu}_{\mathrm{t}}$

While the log-linear function of the model is specified thus;

$\operatorname{LogFD}_{t}=\log \beta_{\mathrm{o}}+\beta_{1} \log M S_{t}+\beta_{2} \log I N F R_{t}+\beta_{3}+\operatorname{LogGDP} P_{t}+\mu_{t}$

Where;

LogFD = Fiscal Deficit -----Dependent Variable

LogMS = Money Supply -------independent Variable

LogINFR = Inflation Rate ------independent Variable

LogGDP) $=$ Gross Domestic Product---independent variable

$\beta_{\mathrm{o}}=$ intercept (Constant term)

$\beta_{1}-\beta_{3}=$ Coefficient of the parameter estimates or the slope

$\mu_{\mathrm{t}}=$ Error term.

$\mathrm{t}=$ time period.

Apriori Expectation $=\beta_{1}, \beta_{2}>0$

\section{Description of Variables in the Study}

Fiscal Deficits: This is the overall or accumulated shortfall of government revenues over government expenditures. Thus the overall gap between government expenditure and government revenue in a given period was used as fiscal deficits. The overall fiscal deficits figure which represents accumulated deficits or surpluses of the Federal Government of Nigeria overtime are used as variables. Overall fiscal deficits are chiefly financed by two broad classifications; Domestic and External Borrowings.

Gross Domestic Product: Gross domestic product is the total value of all final goods and services produced within a given country in a given year. It is also the market value of all officially recognized final goods and services product within a country in a given period of time

Inflation Rate is an annualized percentage change in general price index or consumer price index, over time. Inflation is the rapid and persistent rise in general price level of goods and services in an economy over a period of time. Inflation has a negative impact on economic growth in an economy. It also discourages investment and savings as a result of uncertainty over the future

Money Supply The term money supply refers to the amount in the hands of the non-bank public at a point in time and the some balances in commercial banks. The Central Bank of Nigeria (CBN) as well as public and private analysts shows interest in the growth of money supply because of the impact it is believed to have on real economic activities and the general price level. The growth of money supply will lead to inflation if increase in money supply is not met by equal increase in demand.

\section{Hypotheses Testing}

The research hypotheses are stated as follows

- Ho; there is no positive and significant relationship between Fiscal Deficit and Money Supply.

- Ho; Fiscal deficit does not impact on Inflation Rate. 
INTERNATIONAL JOURNAL OF ACADEMIC RESEARCH ECONOMICS AND MANAGEMENT SCIENCES Vol. 7, No. 3, 2018, E-ISSN: 2226-3624 @ 2018 HRMARS

- Ho; there is no significant association between fiscal deficit and Gross Domestic Product

\section{Presentation of Data, Analysis, Findings and Recommendations}

Table 4.1: shows the Fiscal Deficit, Money supply, and Inflation Rate and GDP in Nigeria (19862018)

\begin{tabular}{|c|c|c|c|c|}
\hline Year & FD in (\%) & MS in( $\left.M^{\prime}\right)$ & INFR in (\%) & GDP in (M') \\
\hline 1986 & $-8,254.3$ & $23,810.0$ & 5.40 & $15,237,990.00$ \\
\hline 1987 & $-5,889.7$ & $27,570.0$ & 10.20 & $15,263,930.00$ \\
\hline 1988 & $-12.160,9$ & $38,360.0$ & 38.30 & $16,215,370.00$ \\
\hline 1989 & $-15,134.7$ & $45,900.0$ & 40.90 & $17,294,680.00$ \\
\hline 1990 & $-22,116.1$ & $52,860.0$ & 7.50 & $19,305,630.00$ \\
\hline 1991 & $-35,755.2$ & $75,400.0$ & 13.00 & $19,199,060.00$ \\
\hline 1992 & $-39,532.5$ & $111,110.0$ & 44.50 & $19,620,190.00$ \\
\hline 1993 & $-107,735,3$ & $165,340.0$ & 57.20 & $19,927,990.00$ \\
\hline 1994 & $-70,270.6$ & $230,290.0$ & 57.00 & $19,979,120.00$ \\
\hline 1995 & $1,000.0$ & $289,090.0$ & 72.80 & $20,353,200.00$ \\
\hline 1996 & $32,049.4$ & $345,850.0$ & 29.30 & $21,177,920.00$ \\
\hline 1997 & $-5,000.0$ & $413,280.0$ & 8.50 & $21,789,100.00$ \\
\hline 1998 & $-133,389.3$ & $488,150.0$ & 10.00 & $22,332,870.00$ \\
\hline 1999 & $-285,104,7$ & $628,950.0$ & 6.60 & $22,449,410.00$ \\
\hline 2000 & -103.8 & $878,460.0$ & 6.90 & $23,688,280.00$ \\
\hline 2001 & -221.0 & $1,269,320.0$ & 18.90 & $25,267,540.00$ \\
\hline 2002 & -202.7 & $1,505,960.0$ & 12.90 & $28,957,710.00$ \\
\hline 2003 & -172.6 & $1,952,920.0$ & 14.00 & $31,709,450.00$ \\
\hline 2004 & -161.4 & $2,131,820.0$ & 15.00 & $35,020,550.00$ \\
\hline 2005 & -101.4 & $2,637,910.0$ & 11.60 & $37,474,950.00$ \\
\hline 2006 & 117.2 & $3,797,910.0$ & 8.20 & $39,995,500.00$ \\
\hline 2007 & -47.38 & $5,127,400.0$ & 6.60 & $42,922,410.00$ \\
\hline 2008 & -810.01 & $8,008,200.0$ & 15.10 & $46,012,520.00$ \\
\hline 2009 & $-1,105,4$ & $9,419,920.0$ & 12.10 & $49,856,100.00$ \\
\hline 2010 & $-1,158.5$ & $11,034,940.0$ & 11.80 & $54,612,260.00$ \\
\hline 2011 & -975.7 & $12,172,490.0$ & 10.40 & $57,511,040.00$ \\
\hline 2012 & $-1,153.5$ & $13,895,390.0$ & 12.00 & $59,929,890.00$ \\
\hline 2013 & $-1,153.5$ & $15,158,620.0$ & 7.90 & $63,218.720 .00$ \\
\hline 2014 & -835.68 & $17,680,520.0$ & 8.01 & $67,152,790.00$ \\
\hline 2015 & $-1,55.79$ & $18,579,418.0$ & 9.60 & $69,023,930.00$ \\
\hline 2016 & $-1,600.78$ & $18,456,300.0$ & 18.29 & $70,567,400.00$ \\
\hline 2017 & -990.76 & $19,450,456.0$ & 15.37 & $72,345,564,00$ \\
\hline 2018 & $-1,780.12$ & $20,560,389.0$ & 11.44 & $73,123.678 .00$ \\
\hline
\end{tabular}

Source: CBN statistical Bulletin various issues, 2018 
INTERNATIONAL JOURNAL OF ACADEMIC RESEARCH ECONOMICS AND MANAGEMENT SCIENCES Vol. 7, No. 3, 2018, E-ISSN: 2226-3624 @ 2018 HRMARS

Data Analysis and Interpretation of Result

Table 4.2 Basic Descriptive Statistics of Variables of the study

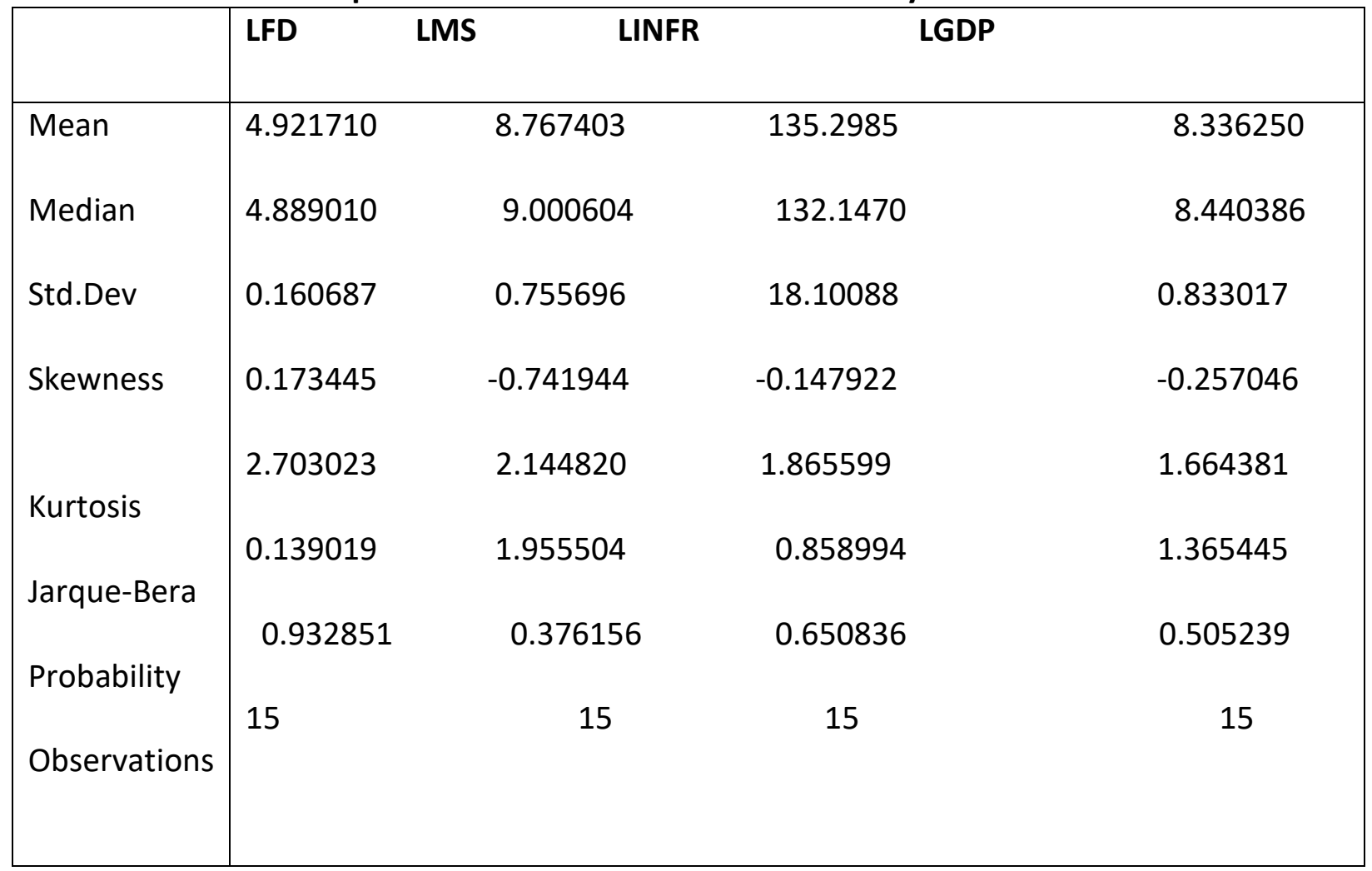

Source: Author's E-view 9 computation (2018)

Table 4.2 shows the basic descriptive statistics of the variables under study. It measures the central tendency like the mean and median which measures how closely knit the variables are. It also contains measures of spread and variations such as the standard deviation. The test for normality is shown by Skewness and Kurtosis with Jacque -Berra which is asymptotic combined test for an S (O), K (3) was also shown in the table. These measure the degree of symmetry of the observation respectively.

Table 4.3: Correlation Results

\begin{tabular}{|lcccc|}
\hline & FD & LMS & LINFR & LGDP \\
\hline FD & 1.000000 & 0.637960 & 0.851406 & 0.823332 \\
LMS & 0.637966 & 1.000000 & 0.824366 & 0.905042 \\
LINFR & 0.823332 & 0.905042 & 1.000000 & 0.881075 \\
LGDP & 0.851406 & 0.823466 & 0.881075 & 1.000000 \\
\hline
\end{tabular}

Source: Author's E-view 9 computation (2018)

Table 4.3 contains the correlation analysis of the variables under study. The result indicates that all the variables positively and significantly correlate with one another with varied percentages. However, the strength of the linear association between LINFR and LMS is about $91 \%$ and the strongest. This implies that LMS is stronger in association with LINFR than the other variables under study. GDP shows a stronger association with LMS than with LINFR considering their percentage degree of relationship of $82 \%$ and $63 \%$ respectively. 


\section{Unit Root Test}

Unit Root Test which shows the stationarity properties of the series is shown in this section. This is necessary to avoid spurious regression. The Augmented Dickey Fuller (ADF) procedure following the form formation by Dickey and Fuller was adopted in testing for existence of unit root in the time series data, as well as the order of integration of the variables

Table 4.4 Augment Dickey Fuller (ADF) Unit Root Test Result

\begin{tabular}{|l|lcc|c|c|c|}
\hline VARIABLE & $\begin{array}{l}\text { ADF } \\
\text { STATISTIC }\end{array}$ & $\begin{array}{l}\text { CRITICAL } \\
@ 5 \%\end{array}$ & VALUE & P VALUE & $\begin{array}{l}\text { ORDEROF } \\
\text { INTEGRATION }\end{array}$ & RMKs \\
\hline LFD & -5.18 & -3.83 & 0.0065 & $1(1)$ & $\begin{array}{c}\text { Stationary at } 1^{\text {st }} \\
\text { differencing } \\
\text { Stationary at } 1^{\text {st }} \\
\text { differencing }\end{array}$ \\
LINFR & -2.13 & -1.97 & 0.0364 & $1(1)$ & $\begin{array}{c}\text { Stationary at } 1^{\text {st }} \\
\text { differencing }\end{array}$ \\
LGDP & -3.91 & -1.97 & 0.0001 & $1(1)$ & $\begin{array}{c}\text { Stationary at } 1^{\text {st }} \\
\text { differencing }\end{array}$ \\
\hline
\end{tabular}

Source: Author's E-view 9 computation (2018)

Table 4.3 shows the test for stationary properties of the series following the Augmented Dickey Fuller statistics. It indicates that all the variables have unit root but attained stationarity at first difference with the ADF statistics for the respective variables being more negative than the critical value at $5 \%$ level of significance. The reported $p$-values are less than 0.05 . Hence, the null hypothesis of the presence of unit root in all the variables is convincingly rejected.

More so the variables are all integrated of the same order significantly co integration among the variables under study as opined by Engle and Granger (1985). They argue that when time series data are integrated of the same order 1(1), the data series tend to co integrate. This implies that their short run relationship is sustainable in the long run. 
INTERNATIONAL JOURNAL OF ACADEMIC RESEARCH ECONOMICS AND MANAGEMENT SCIENCES Vol. 7, No. 3, 2018, E-ISSN: 2226-3624 ㄷ 2018 HRMARS

Table 4.4 Regression Analyses

Dependent Variable: LFD

Method of Least Squares

Date: 07/13/18 Time: 17.07

Sample (adjusted): 1986-2018

Included observations: 15 after adjustments

\begin{tabular}{lcccc} 
Variable & Coefficient & Std, Error & t-Statistic & Prob \\
\hline LMS & 0.176777 & 0.062988 & 2.806535 & 0.0171 \\
LINFR & -0.155125 & 0.060160 & -2.578548 & 0.0257 \\
LGDP (-1) & 0.696195 & 0.274786 & 2.533594 & 0.0278 \\
$\quad$ C & 1.412705 & 0.984168 & 1.435431 & 0.1790 \\
R-square & 0.836685 & Mean dependent VAR & 4.9414922 \\
Adjusted R-square & 0.792144 & S.D.dependent VAR & 0.144922 \\
S.E. of regression & 0.066071 & Akaike info criterion & -2.372981 \\
Sum squared resid & 0 '048020 & Schwarz criterion & -22.184167 \\
Log likelihood & 21.79735 & Hannan-Quinn criter & -2.374992 \\
t-statistic & 18,78481 & Durbin- Watson stat & 2.477386 \\
Prob(F-statistic) & 0.000123 & &
\end{tabular}

In table 4.4, above, LogGDP (1) was used as control variable; LMS shows positive and no significant effect on LMS while LINFR indicate a negative and no significant impact on LFD. The $\mathrm{R}^{2}$ reveals that about $83.7 \%$ of the variations in LFD could be explained by LINFR and LMS while about $17 \%$ (unexplained variation) is blamed on other factors capable of influencing Gross Domestic Product (GDP) that are outside the model. The t-statistics of (18.78481, Prob value $=0.0000123$ at a critical value of 0.05 shows that the overall regression is significant and can be used for meaningful analysis. There is no evidence of a first order autocorrelation AR (1) considering the Durbin Watson statistics (DW) value of 2.47. By rule of thumb, if the DW statistics is approximately equal to 2 , it is evidence against the existence of a first order serial correlation.

\section{Summary of Findings, Conclusion and Recommendations Summary of findings}

- Gross Domestic Product (GDP) has positive and no significant effect on Fiscal Deficit (FD)

- Money supply (MS) has negative and no significant impact on Fiscal Deficit (FD)

- Inflation rate (INFR) has negative and no significant relationship with Fiscal Deposit (FD)

\section{Conclusion}

The study concludes that fiscal deficits have contributed to macroeconomic instability measured in terms of inflation, money supply and gross domestic product (GDP) in Nigeria. Although fiscal deficit objectives may be well intended to stimulate economic growth and employment, its negative impact on inflation, Money Supply and GDP eroded the possible expansionary impact on output, thereby, resulting into poor macroeconomic performances in Nigeria. These findings may not be unconnected with the nature of Nigeria's fiscal operation which is characterized by 
INTERNATIONAL JOURNAL OF ACADEMIC RESEARCH ECONOMICS AND MANAGEMENT SCIENCES Vol. 7, No. 3, 2018, E-ISSN: 2226-3624 @ 2018 HRMARS

fiscal indiscipline, wastes, systemic corruption and unsustainable debt burden, given that deficits are chiefly financed through public borrowing in Nigeria

\section{Recommendations}

> Fiscal Deficit should not be geared towards recurrent expenditure to the detriment of capital expenditure which has the capacity to stimulate employment.

$>$ Government should moderate the level of fiscal deficits and financing of deficit through public borrowing for effective control of inflation rate in Nigeria. This is because increase in fiscal deficits increases money supply which negatively affects output growth in the long-run.

$>$ Government should set it priority rights, be more committed to budget implementation and to pay more attention to capital expenditure geared towards growth.

\section{Other Recommendations}

$>$ Massive investment in infrastructure should be embarked upon such as rehabilitation of rail transport all over Nigeria, resuscitation of textile industries.

$>$ Systemic corruption which is the main reason why fiscal deficit has not positively impacted on macroeconomic indicators should be dissuaded in Nigeria

> Key government institutions should mount programs aimed towards restoring our value system, norms and mind-sets which corruption has destabilized and made weak to be strong again, otherwise, Nigeria will systematically drift into extinction

\section{References}

Anyanwu, J. C. and Oaikhenan, H. E. (1995) Modern Macroeconomics: Theory and Application in Nigeria. Onitsha: Journal of Educational Publishers Limited

Aslam, A. L. M (2016) Budget deficit and economic growth in Sri Lanka: An econometric dynamic analysis. World Scientific News, 46, 176-188

Barro, R. J. (1989) The Richardian Approach to Budget Deficit; Journal of Economic Perspectives, 3 (1) 37-54

Central Bank of Nigeria (2015) Statistical Bulletin: Central Bank of Nigeria. Abuja

Central Bank of Nigeria (2013) Statistical Bulletin. Abuja: Central Bank of Nigeria Abuja

Central Bank of Nigeria Central Bank of Nigeria (2014), Annual Report and Statement of Account Lagos: Central Bank of Nigeria

Chkraboty, P and Chakraborty, L. S. (2016) Is Fiscal Policy Contra cyclical in India online copy.

Egwaikhide, F. O. Chete L.N. and Falo K. G. (1994) Exchange Rate Depreciation, Budge

Deficit and inflation, the Nigerian Experience, OMIC Research Consortium, Research 26 (1) $1-45$

Nnamocha, P. N. (2002) Public Finance for a Developing Economy Owerri, Bon. Publishers. Nwaeze, N. C. (2017) Fiscal Deficit, Financing Options and Macroeconomic Stability in Nigeria: A Disaggregated Approach. Greener Journal of Economics and Accountancy, found 
INTERNATIONAL JOURNAL OF ACADEMIC RESEARCH ECONOMICS AND MANAGEMENT SCIENCES

Online at http://doi.org/10.15580/GJEA.2017.2.090517121.

Ogunsakin, S and Abiola, L. N. (2015) Fiscal Deficit and Economic Growth, Nigeria Experience Found online ISSN 2411-2933, Print-ISSN 2411-3123

Okpanachi, U. M and Abimiku C. A (2007) Fiscal Deficit and Macroeconomic Performance:

Survey of theory and Empirical Evidence- in Ogiji P.ed. The Nigerian Economy:

Challenge and Directors for Growth in the Next 25 Years, Makurdi, Aboki publishers

Oyinlola, O. O and Adam, J. A. (2003) Public Expenditure and Human Development in Nigeria, Human Resource in Development in Africa 53-78

Ozurumba, B. A. (2012) Fiscal Deficit and inflation in Nigeria: The Causality Approach 1(8) 6-12

Sanya, O., and Abiola, L. (2015) Fiscal and Economic Growth, Nigeria Experience. Online ISSN2411-2933, Print-ISSN 2411-3123

Ubi, P., and Inyang, J. (2018) Fiscal Deficit and Nigeria's Economic Development. International Journal of Economics, Commerce and Management, 5(5) 137-150 